\title{
Thermal comfort in naturally ventilated buildings with double skin façade under tropical climate conditions: the influence of key design parameters
}

Corresponding author: Sabrina Barbosa. Telephone: 447564653983 Email: $\underline{\text { s.barbosa@brighton.ac.uk }}$

Double skin façade; Tropical climate; Thermal comfort; Natural ventilation; Design parameters

DSF double skin façade

HVAC heating, ventilation and air conditioning

NPL neutral pressure line

WWR window to wall ratio

SC shading coefficient

\begin{abstract}
This paper evaluates the influence of key design parameters on the thermal behaviour of a naturally ventilated building with Double Skin Façade (DSF) under tropical climate conditions. Using a reference model of a conventional office building in the city of Rio de Janeiro and two groups of design parameters, dynamic thermal simulations are systematically applied to optimise design options with the aim to maximize the annual acceptable thermal comfort levels within the occupied spaces. This study not only defines the dimensional parameters to maximise the system airflows, but also investigates the significance of design decisions such as thermal mass and shading devices on the system performance. Options to avoid unintentional reverse flow on the upper floors and maintenance of balanced horizontal airflow rates across the floors are also addressed.
\end{abstract}

Two optimized naturally ventilated building models with DSF are developed and evaluated in terms of thermal performance. Results show that acceptable thermal comfort levels can be met for nearly $70 \%$ of the occupied hours. Although the office building will still require other means of cooling during peak summer periods, the incorporation of DSF as part of a mixed-mode ventilation strategy can potentially have a significant impact on annual energy consumption.

\section{Highlights}

- Optimised DSF models demonstrate acceptable thermal comfort levels for nearly $70 \%$ of the occupied hours

- Shading device characteristics are the most influential parameter on the thermal performance of DSF

- Extending the cavity height by one and a half floors above the roof avoids reverse airflows on the upper floors

- Similar airflows on all floors can be achieved by optimizing the free area of window openings 


\subsection{Introduction}

Double skin façade (DSF) is an architectural element that has recently gained recognition in modern office buildings as a solution for highly glazed façades to reduce the annual HVAC system loads [1]. A typical DSF consists of an additional fully glazed external skin installed over the conventional building façade, forming an air cavity in which sunshade devices are often installed to protect the internal rooms from overheating caused by excessive solar heat gains. The working principle of the technology is highly dependent on the climactic context [2-4], and this dependency accentuates when dealing with naturally ventilated buildings. The majority of the existing studies on DSF are however based on air-conditioned models that regard the DSF cavity as an 'isolated' structure, and often treated as a local thermal feature without taking into account its interaction with the user space [5].

Some studies have attempted to establish the overall airflows in naturally ventilated buildings with DSFs [6, 7], but integrated design strategies enabling effective and desirable airflows on each floor of multi-storey office buildings, in particular for warm and hot climates, are yet to be developed and analysed. This study is therefore an attempt to address this knowledge gap by systematically evaluating the influence of the key design parameters through computational dynamic simulation, with the aim to establish optimised models that enable detailed studies of the thermal performance when operating under the tropical climate.

In the following sections, the working principle of the DSF in naturally ventilated buildings is introduced followed by the development of the generic base case model used in the simulations, including the architectural features and the internal gains profile, as well as the justification for the selection of the key design parameters for evaluation. Modelling, climate characterization, development of optimised models and simulation processes are described leading to critical evaluations of the impacts of the key design parameters on the building thermal performance. The paper concludes on the implications and significance of the findings to the wider application and research of DSF in tropical climates.

\subsection{Working principle}

The flow of air in the cavity of a DSF is mainly driven by solar-induced thermal buoyancy and pressure variations resulting from the effects of airflow (wind) around the building. The thermal buoyancy within the DSF generates a pressure difference which drives air flow as a function of the temperature difference between the warmer cavity air and the surrounding cooler air. 


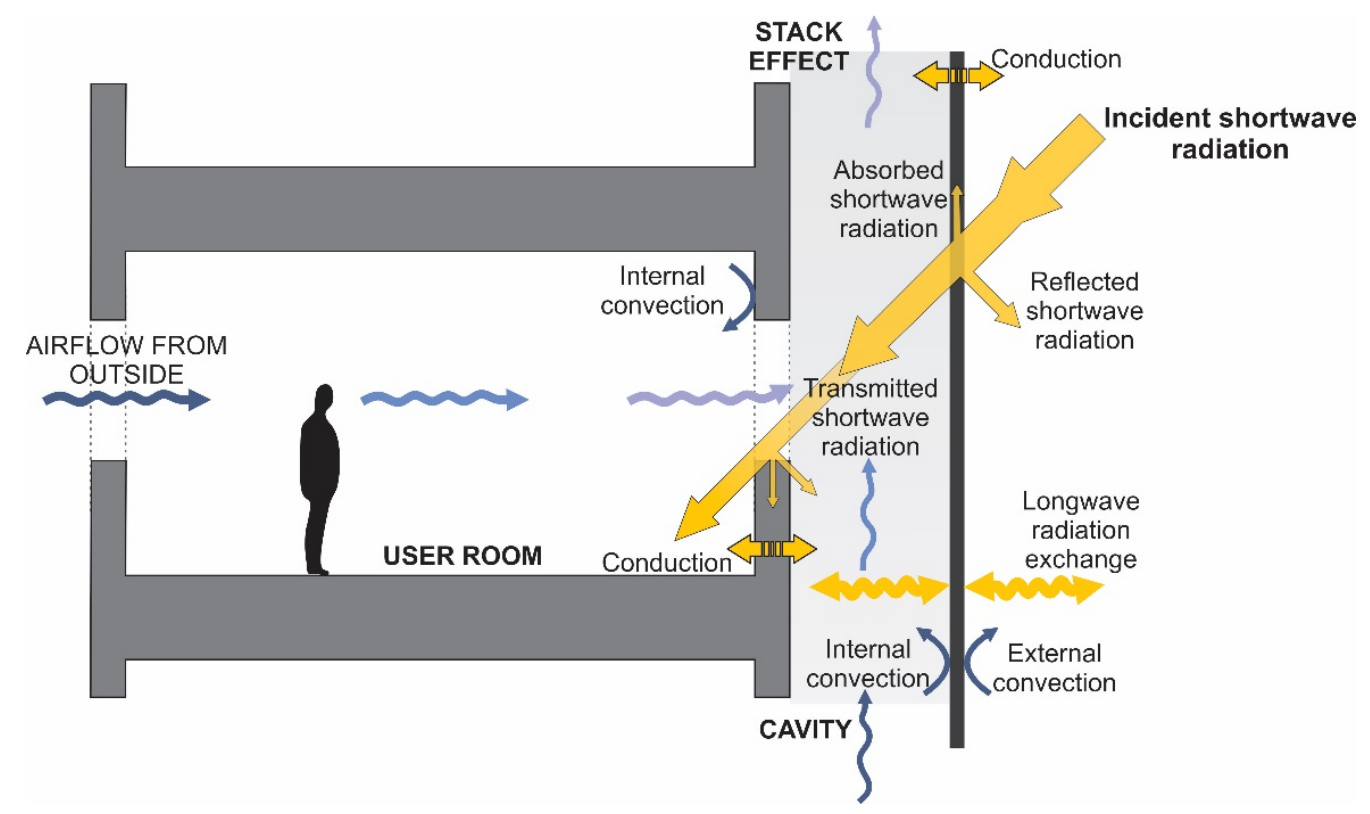

Figure 1 - DSF and the adjacent office floor cross-section with the heat transfer and airflow mechanisms

In a naturally ventilated building with DSF, outdoor air is supplied from openings in the opposite façade and passes through the occupant space before entering the cavity. This air is then heated by solar and conduction gains, rises up and the resulting lowering of air pressure continues to draw air from the adjacent rooms, forming a continuous convective air stream [6, 8] as shown in Figure 1. The following empirical equation [9] shows that the key variables determining the airflow in a simple thermal chimney are its height, cross-sectional area, location of the openings and the temperature difference between the air in the cavity and the external air.

$$
\mathrm{Q}=\mathrm{C}_{\mathrm{D}} \mathrm{A} \sqrt{2 \mathrm{~g} \Delta \mathrm{H}_{\mathrm{NPL}}\left(\mathrm{t}_{\mathrm{i}}-\mathrm{t}_{\mathrm{o}}\right) / \mathrm{t}_{\mathrm{i}}} \quad \text { Equation } 1
$$

Where: $\mathrm{Q}=$ air flow rate, $\mathrm{m}^{3} / \mathrm{s} ; \mathrm{C}_{D}=$ discharge coefficient of the opening; $\mathrm{A}=$ area of the opening, $\mathrm{m}^{2} ; \mathrm{g}=$ acceleration due to gravity, $\mathrm{m} / \mathrm{s}^{2} ; \Delta \mathrm{H}_{\mathrm{NPL}}=$ vertical distance from the neutral pressure line (NPL) to the aperture, $\mathrm{m} ; \mathrm{t}_{\mathrm{i}}=$ air temperature in cavity (higher temperature), $\mathrm{K} ; \mathrm{t}_{\mathrm{o}}=$ outdoor temperature (lower temperature), $\mathrm{K}$.

However, in a real building these variables are highly influenced by a number of interacting factors such as the building compartmentation, the thermal properties of building fabric and glazing, and the internal heat gains. An important variable of the equation is the height of the neutral pressure line (NPL), which is defined as the point at which the inside and outside pressure gradients intersect and it determines the direction and magnitude of the airflows from the apertures [10]. As the location of the NPL is influenced by air leakage distribution over the building exterior and by the interior compartmentation of the building, it is not unique or necessarily located at the mid-height of a building. NPL may also exist locally across the vertical height of an opening, such as a window connecting the room and the cavity. This can cause local air recirculation which consequentely disturbs the overall air exchange between the two spaces [10]. 
Air movement resulted from varying surface pressures due to wind acting across the building envelope is another important parameter. Studies by Gratia and De Herde [7] and Lou, Huang [11] indicate that the airflows in the cavities reach their minimum when the wind direction is parallel to the façade but they increase when perpendicular, especially if the DSF is located at the leeward side of the building. In reality wind and thermal stack effects never act in isolation and the magnitude and pattern of natural air movement through a building depends on the strength and direction of these natural driving forces and the resistances in the flow paths. When available and aptly applied, wind pressures can play a significant and enhancing role in driving air flows in the DSF. The wind pressure should therefore be utilised to promote airflow from the user room to the cavity although sometimes it may mask the thermal buoyancy effect. However, this study is conducted without the interference of wind in order to establish the baseline level of thermal comfort acceptance focusing on the understanding of the integrated influences of the identified design parameters.

\subsection{Key design parameters}

Two groups of design parameters identified by Barbosa and Ip [5] as having significant impacts on the performance of DSFs relevant to this study are: the 'façade' parameters - which comprise the features of the cavity and the external layer of the DSF and; the 'building' parameters - that involve the physical configurations of the building. Parameters identified and adopted in this study and their relevance to the performance of DSFs are summarised in Table 1. Their investigation also found that no suitable naturally ventilation model exists as most of the existing studies were conducted based on air-conditioned buildings. However, some of the generic principles identified on the air conditioned models can be applied to naturally ventilated buildings and they are therefore adapted as guidance in defining the design parameters and in developing the base case and alternative case models for the simulations. 


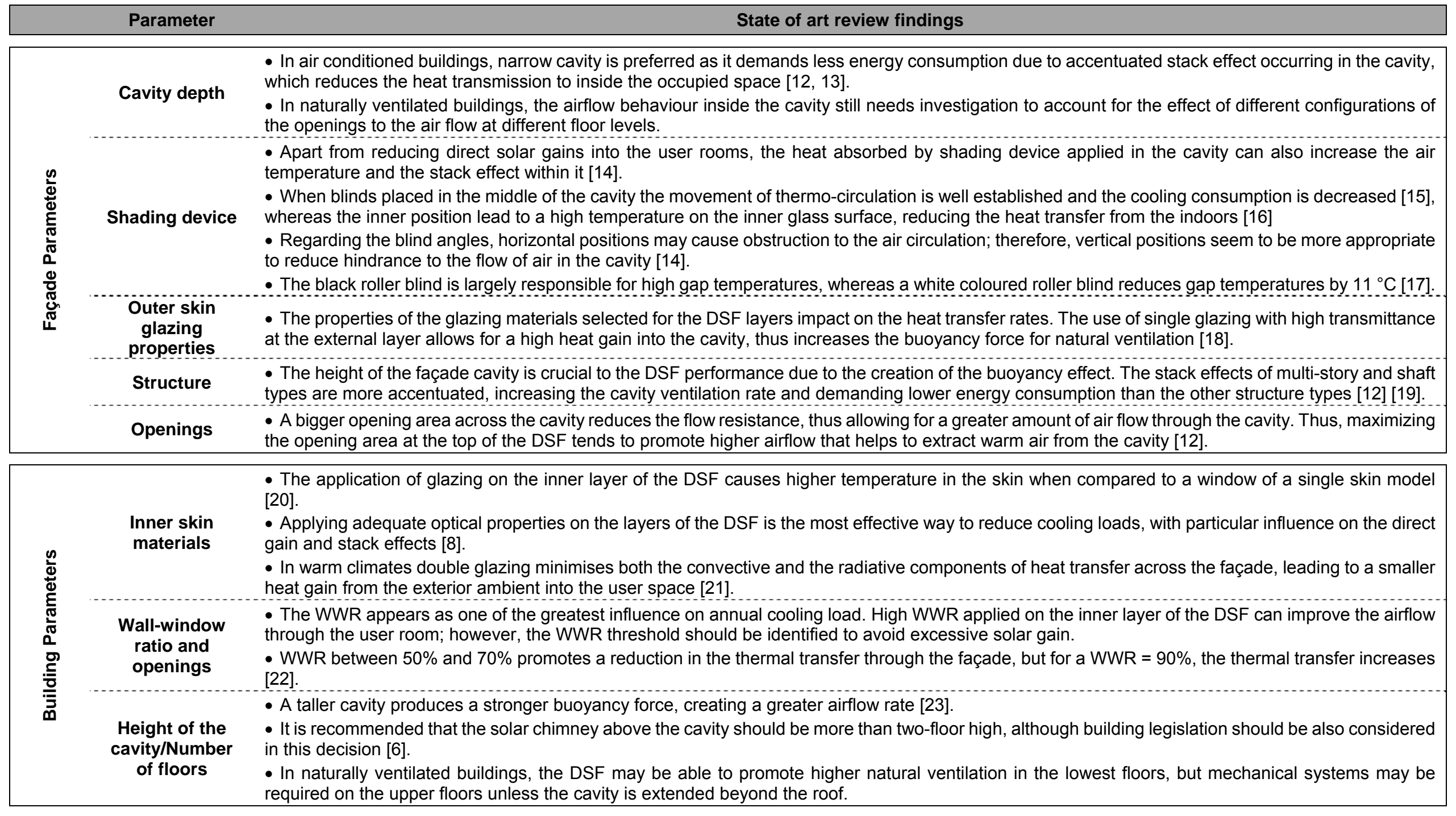




\subsection{Methodology}

\subsection{Base case}

The base case model is used as a benchmark reference for evaluating the performance when different controlled and variable parameters are applied. Development of the model is based on a topology study of office buildings in Brazil by Carlo [24] and future office layout by Voordt and Maarleveld [25]. The model developed comprises of 11 floors of open plan office of dimensions $12 \mathrm{~m} \times 15.5 \mathrm{~m}$ and $3.5 \mathrm{~m}$ floor-to-floor height, with longest side facing north/south.

Selection of envelope composition draws on the recommendations from the Brazilian code for thermal performance of buildings [26], the relevant construction examples by Morishita, Sorgato [27] and study of predominant window to wall ratio (WWR) in office buildings by Carlo [24]. The model preserved the typical Brazilian wall construction which consists of an insulation material sandwiched between two layers of ceramic block, plastered and finished in white. Both the south and north façades have WWR of $50 \%$ with windows placed across the width and at mid height of the floor.

A north facing multi-storey type DSF, without any interior vertical or horizontal partitions [28], with a depth of $50 \mathrm{~cm}$ is selected, covering the entire face of the building from the first floor. Thermal properties of the principal elements of the building fabric, occupancy profile and the internal gains are summarised in Table 2.

Table 2 - Characterisation of the building model

\begin{tabular}{|c|c|c|c|c|}
\hline \multicolumn{5}{|c|}{ Building envelope } \\
\hline \multicolumn{5}{|c|}{ Roof: $\mathrm{U}$ value $=0.18 \mathrm{~W} / \mathrm{m}^{2} \mathrm{~K}$} \\
\hline \multicolumn{5}{|c|}{ Ground floor: $\mathrm{U}$ value $=0.28 \mathrm{~W} / \mathrm{m}^{2} \mathrm{~K}$} \\
\hline \multicolumn{5}{|c|}{ Masonry walls: $U$ value $=0.61 \mathrm{~W} / \mathrm{m}^{2} \mathrm{~K}$} \\
\hline \multicolumn{5}{|c|}{ WWR $=50 \%$} \\
\hline \multicolumn{5}{|c|}{ Outer layer of DSF } \\
\hline \multicolumn{5}{|c|}{$12 \mathrm{~mm}$ clear single glass: $U$ value $=3.9 \mathrm{~W} / \mathrm{m}^{2} \mathrm{~K}$} \\
\hline \multicolumn{3}{|c|}{ Transmittance $=0.67$} & \multicolumn{2}{|c|}{$\begin{array}{c}\text { Figure } 2 \text { - Axonometric view of the } \\
\text { building model }\end{array}$} \\
\hline \multirow[b]{3}{*}{$\begin{array}{l}\text { Occupancy } \\
8 \text { am }-6 \text { pm }\end{array}$} & Internal gain & & Lighting & \multirow[b]{2}{*}{$\begin{array}{l}\text { Total } \\
{\left[\mathrm{W} / \mathrm{m}^{2}\right]}\end{array}$} \\
\hline & $\begin{array}{l}\text { People } \\
{\left[\mathrm{W} / \mathrm{m}^{2}\right]}\end{array}$ & $\begin{array}{l}\text { Equipment } \\
{\left[\mathrm{W} / \mathrm{m}^{2}\right]}\end{array}$ & {$\left[\mathrm{W} / \mathrm{m}^{2}\right]$} & \\
\hline & 9.8 & 8.4 & 18.7 & \multirow{2}{*}{36.9} \\
\hline $\begin{array}{c}\text { Non } \\
\text { occupancy }\end{array}$ & 0.0 & 0.0 & 0.0 & \\
\hline
\end{tabular}

\subsection{Defining parameters}


The parameters and variables to apply in the simulation models are divided into four groups summarised in Table 3 and graphical representations of the corresponding scenarios are shown in Figure 3 . The parameters of 'cavity width', 'cavity bottom opening' and 'window positions' in group A are tested to maximize the absolute air flow extraction by natural ventilation by varying the cavity width, closure of the cavity bottom aperture and repositioning of the windows. Group B consists of the 'shading devices' and 'inner skin material', which deal with the thermal mass of shading devices in the cavity as well as materials used on the inner layer of the DSF. Group $C$ attempts to resolve the low or unintentional reverse flows through the upper floors of the building to reduce the risk of severe overheating by extending the cavity above the roof and closure of some windows openings to the DSF. The last group aims to achieve even horizontal airflows across each floor by adjusting the window opening areas and the gradual increase of cavity width with height.

Table 3 - Parameters and variables defined for simulations

\begin{tabular}{|c|c|c|c|c|}
\hline & Case & $\begin{array}{c}\text { Design } \\
\text { parameter }\end{array}$ & Scenario & Variables \\
\hline \multirow{3}{*}{$\begin{array}{l}\varangle \\
\frac{0}{\bar{z}} \\
\frac{0}{0}\end{array}$} & $\mathrm{~A} 1$ & Cavity width & $\begin{array}{r}\mathrm{A} 1.1 \\
* \mathrm{~A} 1.2 \\
\mathrm{~A} 1.3\end{array}$ & $\begin{array}{l}\text { - } 25 \mathrm{~cm} \\
\text { - } \quad 50 \mathrm{~cm} \\
\text { - } 100 \mathrm{~cm}\end{array}$ \\
\hline & A2 & $\begin{array}{l}\text { Cavity } \\
\text { bottom } \\
\text { opening }\end{array}$ & ${ }^{*} \mathrm{~A} 2.1$ & $\begin{array}{l}\text { - Bottom open } \\
\text { - Bottom closed }\end{array}$ \\
\hline & A3 & $\begin{array}{l}\text { Windows } \\
\text { positions }\end{array}$ & ${ }^{*} \mathrm{~A} 3.1$ & $\begin{array}{l}\text { - North and south walls in the middle of the wall } \\
\text { wall }\end{array}$ \\
\hline \multirow{2}{*}{$\begin{array}{l}m \\
\frac{0}{\bar{T}} \\
\frac{0}{0}\end{array}$} & B1 & $\begin{array}{l}\text { Shading } \\
\text { devices }\end{array}$ & $\begin{array}{r}{ }^{*} \mathrm{~B} 1.1 \\
\mathrm{~B} 1.2 \\
\mathrm{~B} 1.3\end{array}$ & $\begin{array}{l}\text { - No shading device } \\
\text { - Concrete } \\
\text { - } \text { Metal }\end{array}$ \\
\hline & B2 & $\begin{array}{l}\text { Inner skin } \\
\text { material }\end{array}$ & $\begin{array}{r}* \mathrm{~B} 2.1 \\
\mathrm{~B} 2.2\end{array}$ & $\begin{array}{l}\text { - Masonry (white wall) } \\
\text { - Low emissivity reflective double glazing }\end{array}$ \\
\hline \multirow{2}{*}{$\begin{array}{l}0 \\
\frac{0}{\bar{T}} \\
\frac{0}{0}\end{array}$} & C1 & $\begin{array}{l}\text { Cavity } \\
\text { extension } \\
\text { above roof }\end{array}$ & $\begin{array}{l}* \mathrm{C} 1.1 \\
\mathrm{C} 1.2 \\
\mathrm{C} 1.3 \\
\mathrm{C} 1.4\end{array}$ & $\begin{array}{l}\text { - } \text { Cavity height }=\text { building height } \\
\text { - } 1.75 \mathrm{~m} \text { above roof } \\
\text { - } 3.5 \mathrm{~m} \text { above roof } \\
-\quad 5.25 \mathrm{~m} \text { above roof }\end{array}$ \\
\hline & $\mathrm{C} 2$ & $\begin{array}{l}\text { Upper } \\
\text { windows } \\
\text { closed }\end{array}$ & $\begin{array}{r}* \mathrm{C} 2.1 \\
\mathrm{C} 2.2 \\
\mathrm{C} 2.3\end{array}$ & $\begin{array}{l}\text { - All windows open } \\
\text { - Window of } 10^{\text {th }} \text { floor closed } \\
\text { - Windows of } 9^{\text {th }} \text { and } 10^{\text {th }} \text { floors closed }\end{array}$ \\
\hline \multirow{2}{*}{$\begin{array}{l}0 \\
\frac{0}{3} \\
\frac{0}{0}\end{array}$} & D1 & $\begin{array}{l}\text { Tapered } \\
\text { cavity }\end{array}$ & $\begin{array}{r}* \mathrm{D} 1.1 \\
\mathrm{D} 1.2 \\
\mathrm{D} 1.3\end{array}$ & $\begin{array}{l}\text { - Equal cavity width over the floors } \\
\text { - Inclined outer skin (base }=100 \mathrm{~cm} ; \text { top }=20 \mathrm{~cm} \text { ) } \\
\text { - Inclined inner skin (base }=100 \mathrm{~cm} \text {; top }=20 \mathrm{~cm})\end{array}$ \\
\hline & D2 & $\begin{array}{l}\text { Windows } \\
\text { sizes }\end{array}$ & $\begin{array}{r}* \mathrm{D} 2.1 \\
\mathrm{D} 2.2\end{array}$ & $\begin{array}{l}\text { - Equal windows size over the floors } \\
\text { - Calculated window sizes }\end{array}$ \\
\hline
\end{tabular}




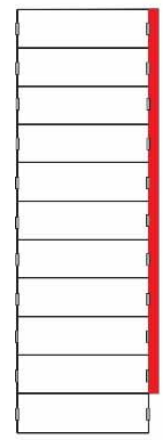

Case

A1

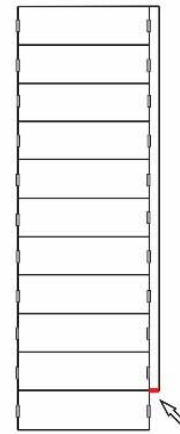

Case

A2

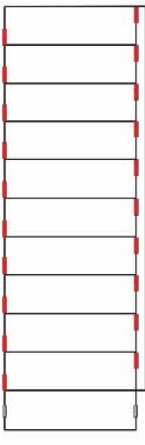

Case

A3

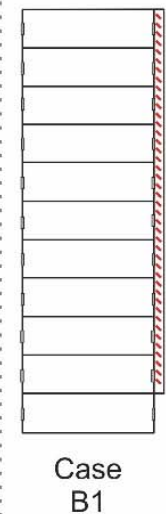

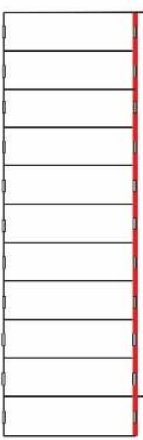

Case

B2

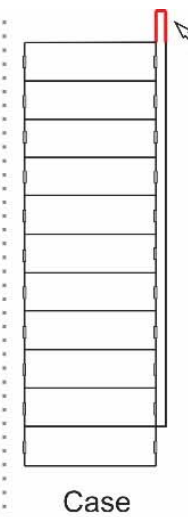

C1

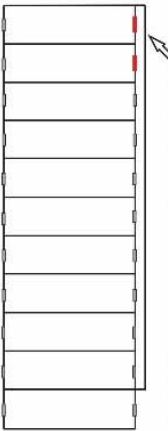

Case

C2

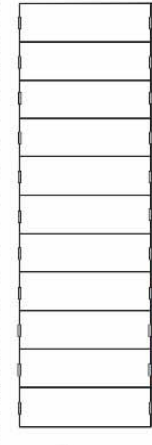

Case

D1

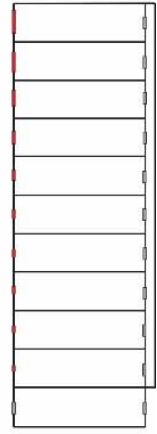

Case

D2

Group A

Group C

Group D

Figure 3 - Pictorial diagrams of the simulation scenarios

\subsection{Simulation modelling and climate characterization}

A total of 17 (base case plus 16 alternatives) naturally ventilated building models with DSF were tested in the building thermal simulation software IESVE [29], which used the airflow network approach based on (macroscopic) zone mass balance and inter-zone flow-pressure relationships [30].

The weather data of Rio de Janeiro (Brazil), which is a tropical city with hot and humid climate according to the Köppen-Geiger's system classification [31], was selected for this study. Psychometric analysis based on the software Analysis Bio from the Federal University of Santa Catarina in Brazil [32] indicated $64 \%$ of hours in thermal discomfort in such climate due to the occurrence of high temperatures and relative humidity; with annual averages of $27^{\circ} \mathrm{C}$ and $80 \%$ respectively. Although mechanical cooling is necessary during the summer, Brazilian Association of Technical Standards [26] recommended the exploitation of passive strategies using natural ventilation as it could potentially satisfy comfort requirement as high as $61 \%$ of the year. Moreover, high solar availability of this city over the year with mean annual global radiation of $211 \mathrm{~W} / \mathrm{m}^{2}$, as shown in Figure 4, offers a source of heat that can be used to drive the airflow through the DSF. 


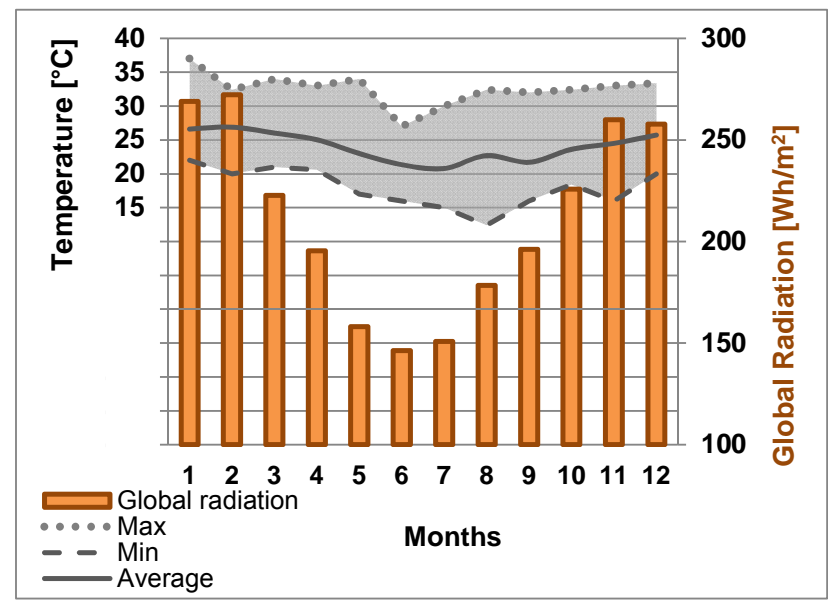

Figure 4 - Monthly average temperature and global radiation of Rio de Janeiro

Acceptability limit for typical building applications in the thermal comfort evaluation is based on the requirements for acceptable thermal indoor environments of ASHARE-55 [33], which takes into account the outdoor air temperature, the indoor air speed and the indoor operative temperature. The simulated cases meet with the conditions considered by ASHARE-55 [33] as the standard is primarily intended for naturally conditioned spaces where near sedentary physical activity levels as those typical of office work, with metabolic rates ranging from 1.0 to 1.3 met, are performed and where occupants may freely adapt their clothing to the indoor and /or outdoor thermal conditions within a range at least as wide as 0.5-1.0 clo.

\subsection{Results and discussion}

This section presents a selection of the resulting air flows for the base case and for all the variables defined. For each alternative case, the annual average net airflow through the north windows of all floors is presented. The positive values indicate net airflows moving from the offices towards the cavity whereas the negative values represent reverse flows. In addition, for the base case, the annual operative temperatures of all the floors according to different seasons of the year are presented based on the ASHARE 55 [33] thermal comfort matrix.

\subsection{Base case}

Figure 5 shows the hourly averages of the direct solar radiation incident on the north façade and the corresponding outside and cavity temperatures for the base case. The increase in cavity temperature bears a direct but non-linear relationship to the amount of solar radiation reaching the façade. The annual average of the differences between these temperatures reaches a maximum at midday of $5.7^{\circ} \mathrm{C}$ while on a sunny day this can reach up to $9.8^{\circ} \mathrm{C}$. 


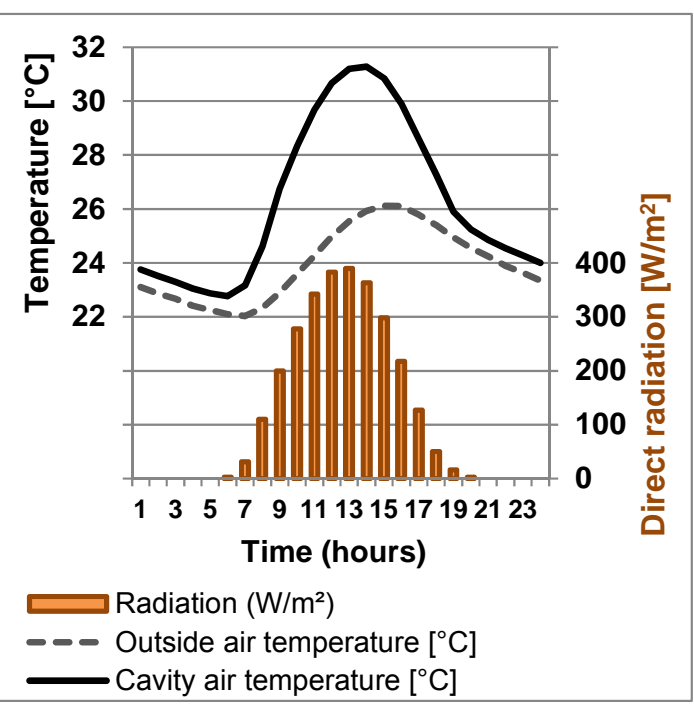

Figure 5 - Annual mean outside and cavity temperature distribution and direct radiation on the north façade

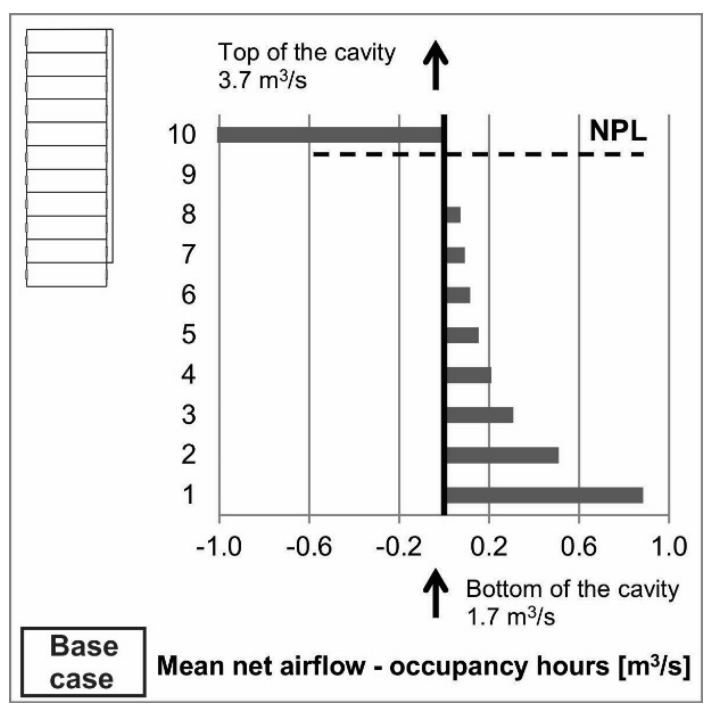

Figure 6 - Annual mean of the net airflow for each floor for the base case

The mean annual net airflows for each floor, top and bottom of the cavity are shown in Figure 6 . Airflows across each floor gradually reduces and on floors above the neutral pressure line NPL on the $9^{\text {th }}$ floor, when the pressure in the cavity is higher than the adjacent window, air flow changes from the cavity towards the occupied space.

Figure 7 is a plot of the ASHARE 55 [33] thermal comfort matrix showing the annual operative temperatures that fall within and outside the acceptable limits between $1^{\text {st }}$ and $10^{\text {th }}$ floors. Using yearly percentages in terms of comfortable and uncomfortable sensations during occupied hours (both due to too hot/too cold conditions) for each floor, Figure 8 shows the base case achieved an average of $61.6 \%$ of occupied hours of acceptable thermal comfort, varying between $43.9 \%$ on the top floor and $70.2 \%$ on the bottom floor. Although the net airflow on the $10^{\text {th }}$ level is negative, the higher air speed and moderate cavity temperatures during milder seasons explain the thermal comfort acceptability over $40 \%$ of the time. 


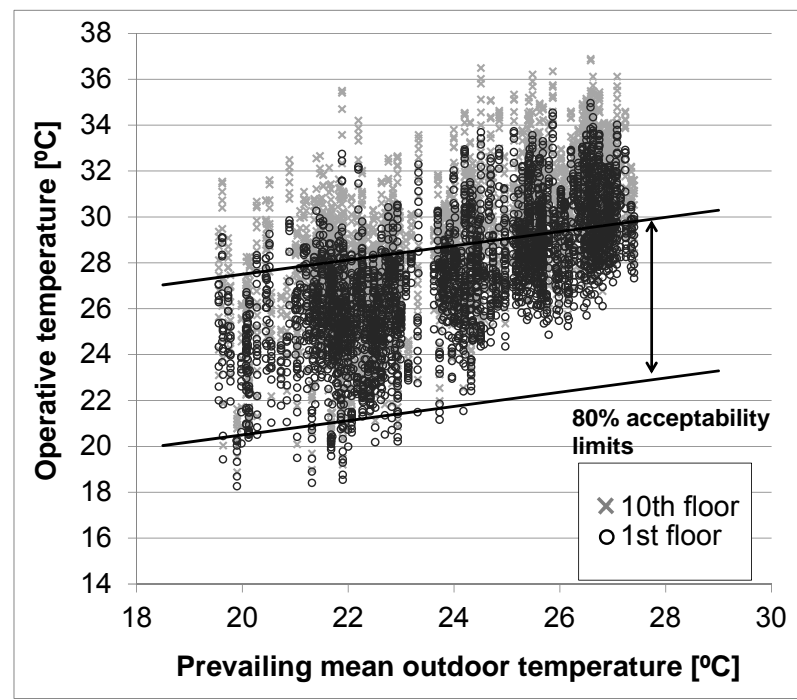

Figure 7 - Annual operative temperatures of the base case (1 $1^{\text {st }}$ and $10^{\text {th }}$ floors) plotted on the ASHRAE [33] thermal comfort matrix

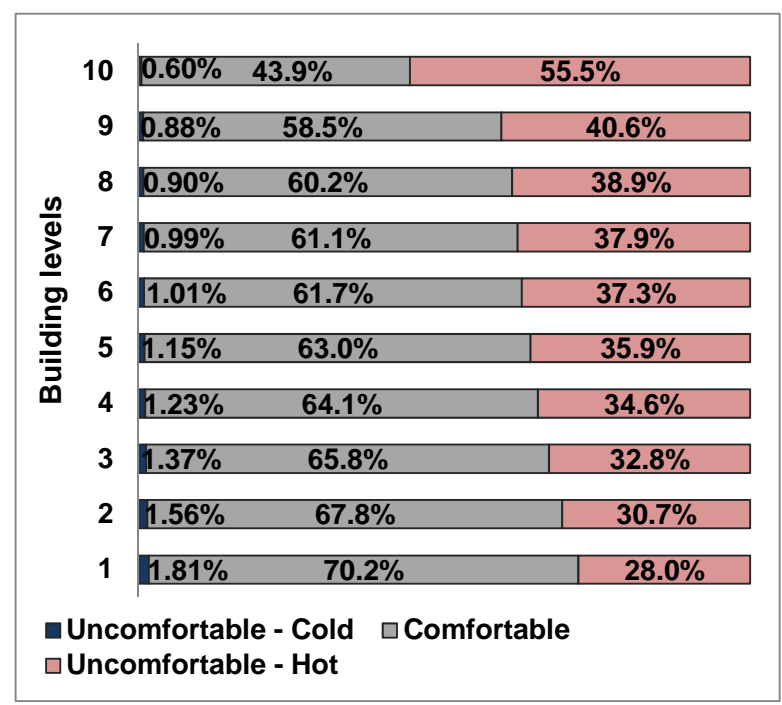

Figure 8 - Annual distribution of thermal comfort (\%) on each floor of the base case

\subsection{Group A: cavity width, cavity bottom opening and windows positions}

Two cavity widths of $25 \mathrm{~cm}$ (case A1.1) and $100 \mathrm{~cm}$ (case A1.3) were tested. The results show that although a marginal higher air cavity temperature of $0.8^{\circ} \mathrm{C}$ on average occurred in the narrower cavity in relation to the wider one, the airflow rates through the offices were lower than the base case (Figure 9) due to the greater flow resistance within the cavity. Although airflow improvement of $115 \%$ was observed when a wider cavity was used, the mean room air speed increase in the offices is small; this resulted in minor improvement of only $2.3 \%$ on the overall acceptable level of thermal comfort.

In order to increase the airflow drawn from the offices, case scenario A2.2 had the aperture of the cavity bottom closed. Figure 10 shows such a change resulted in threefold increase in the net airflow on the $1^{\text {st }}$ floor compared to the base case but only small differences in the other floors. The reduction of air supplied by the bottom cavity aperture caused a drop of pressure in this region, which created a higher pressure difference between the first floor and the section of the cavity in front of it. On the upper floors, this pressure differential is balanced and airflow rates similar to the base case are observed. The mean annual increase in air speed on the $1^{\text {st }}$ floor enhanced the acceptable thermal comfort level on this floor by $4.5 \%$.

In case scenario A3.2, the south windows were placed to the bottom and the north windows to the top of the walls to enhance the buoyancy force through greater height difference between their inlet and outlet apertures. The results are particularly noticeable on the $1^{\text {st }}$ and $10^{\text {th }}$ floors, as shown in Figure 11 . 


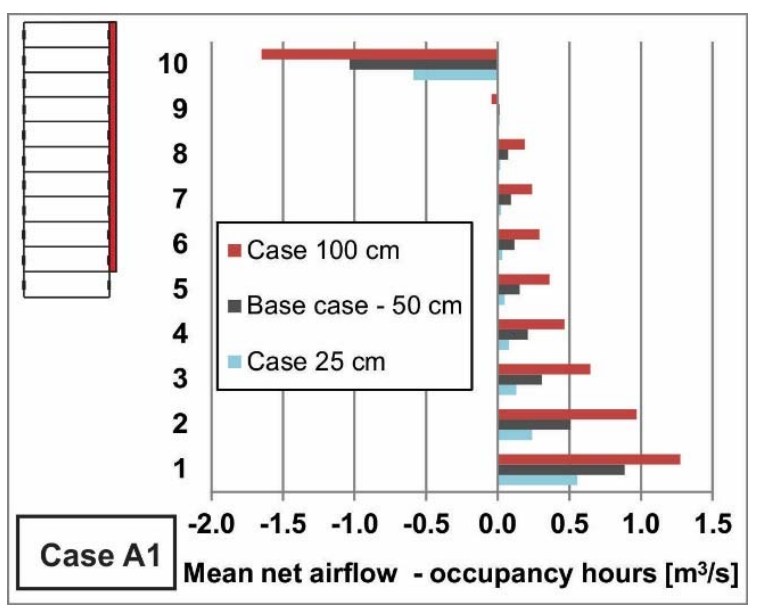

Figure 9 - Annual mean of the net airflow for each floor for parameter 'cavity width'

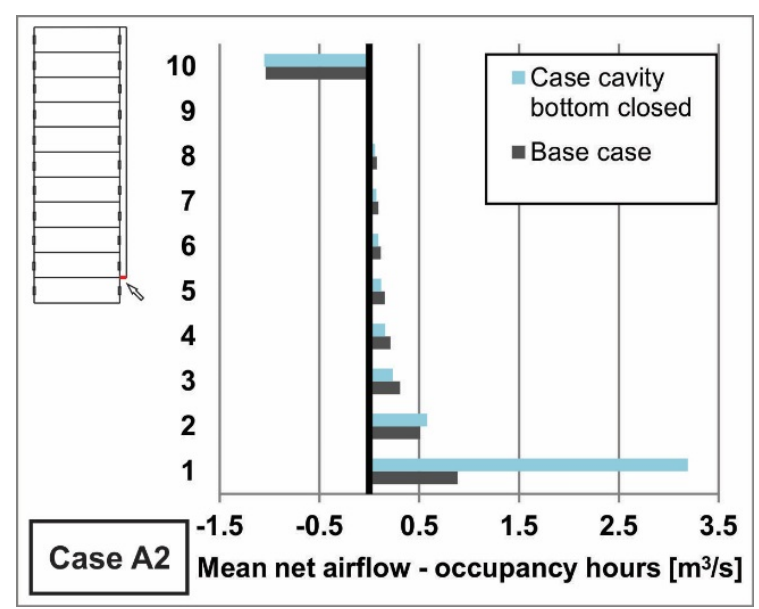

Figure 10 - Annual mean of the net airflow for each floor for parameter 'cavity bottom opening'

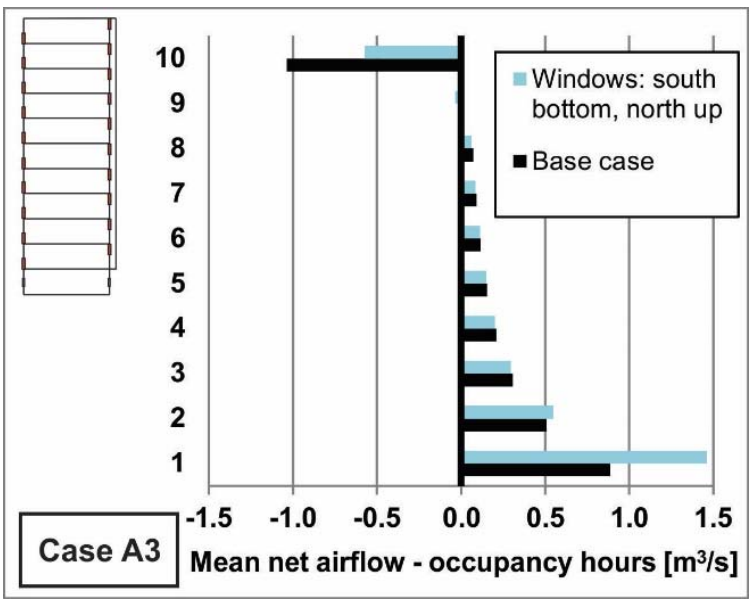

Figure 11 - Annual mean of the net airflow for each floor for parameter 'windows position'

\subsection{Group B: shading device and inner skin material}

In case scenario B1.2, when shading device made of concrete of higher thermal mass was applied within the cavity, higher cavity temperatures were resulted due to the higher absorptance property of the material, whereas when aluminium was selected (case B1.3), lower cavity temperatures were observed, both relative to the base case. Figure 12 illustrates those cases on the winter solstice day, when the differences among the cases are likely to be more pronounced.

Although the application of metal shading device within the cavity reduced the overall airflow in the offices as shown in Figure 14, this option improved the thermal comfort in the building by $9 \%$ in relation to the base case, which can be explained by the reduction in direct solar and conduction heat gains from the cavity. On the other hand, the use of concrete increased heat gains from cavity to the occupied spaces; hence the improvement in the overall building thermal comfort relative to the base case was of only $4.3 \%$. 


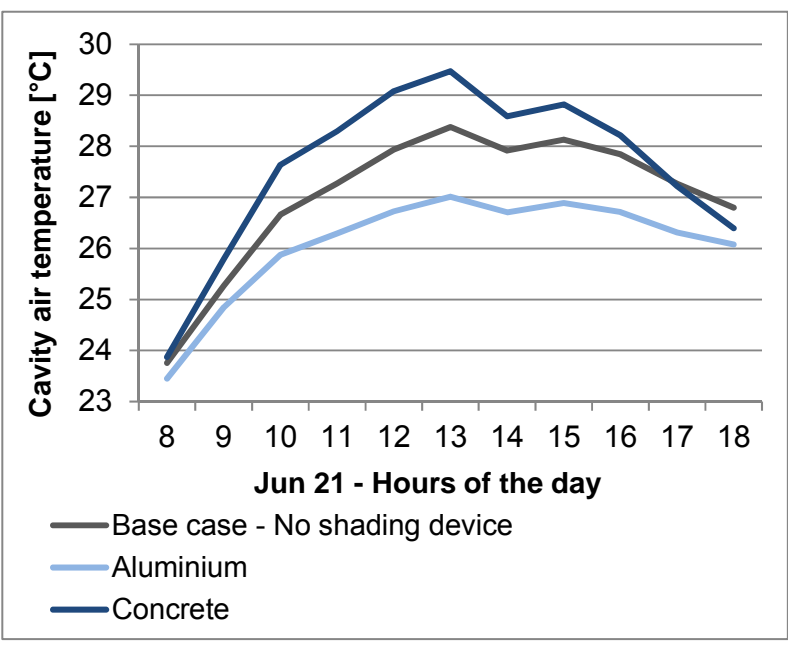

Figure 12 - Cavity temperature for the alternatives of case scenario B.1 'shading device'

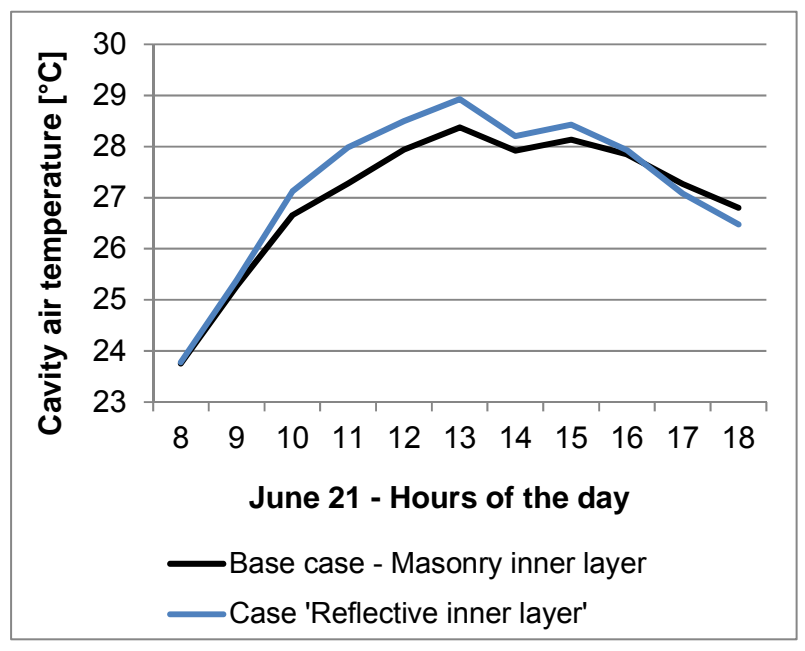

Figure 13 - Cavity temperature for the alternatives of case scenario B.2 'inner reflective skin'

Figure 15 shows that the use of fully reflective glazing on the inner DSF skin (case scenario B2.2) resulted in a similar trend of net airflows through the north windows as the base case with only a reduction of $2 \%$ on the overall thermal comfort. This can be attributed to the higher solar heat gains into the offices and higher convective gains from the cavity as its temperature tend to be higher than the base case (Figure 13).

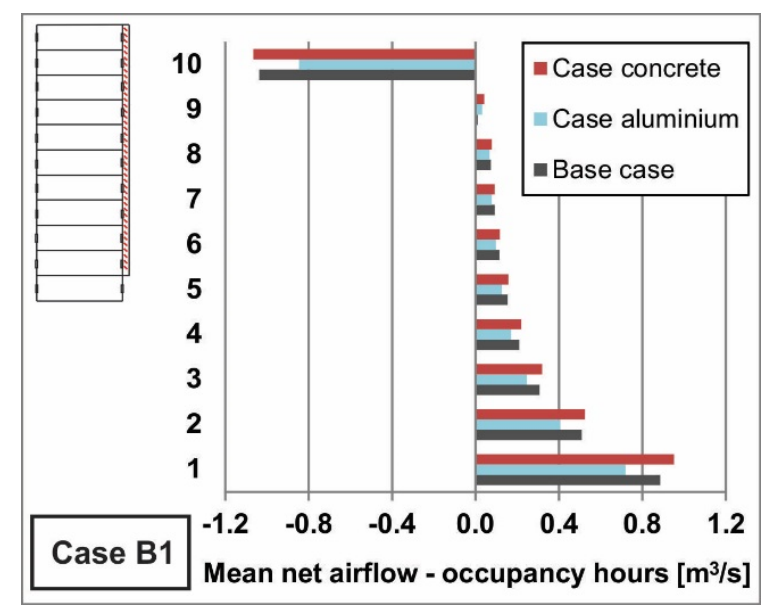

Figure 14 - Annual mean of the net airflow for each floor for parameter 'shading device'

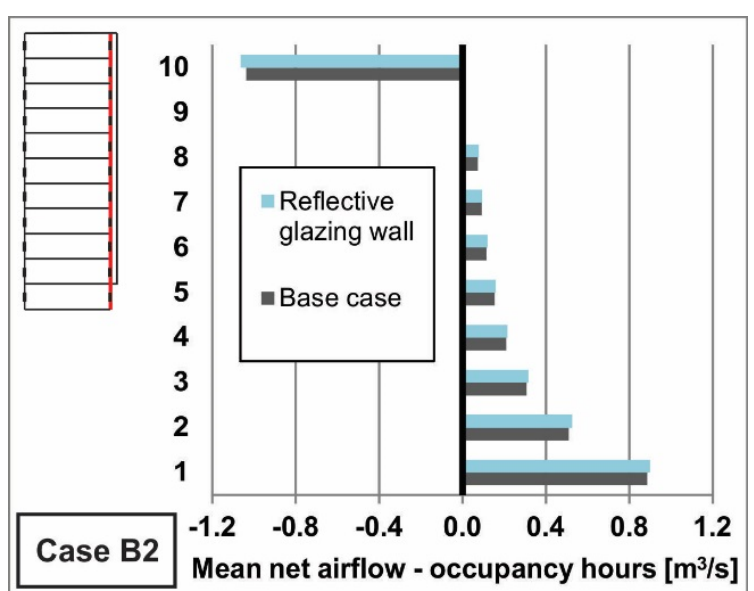

Figure 15 - Annual mean of the net airflow for each floor for parameter 'inner skin material'

\subsection{Group C: cavity extension above roof and upper windows closed}

Cases in group $\mathrm{C}$ were used to resolve the reverse in flow direction on the top floor of the building model by extending the height of the cavity $(175,350$ and $525 \mathrm{~cm}$ above the roof) to raise the NPL above the highest window of the building (case scenarios C1). Figure 16 shows the extension of $525 \mathrm{~cm}$ (one and half floor) achieved the intended ventilation flow paths on all floors with thermal comfort enhancement of $9 \%$ on the top floor compared to the base case. 
When extending the cavity height above the top of the building is not viable, mechanical ventilation for the upper floors with windows closed should be considered as tested in case scenarios C2. Results in Figure 17 shows that closing windows on the top three floors would be necessary to ensure no reverse flow to occur.

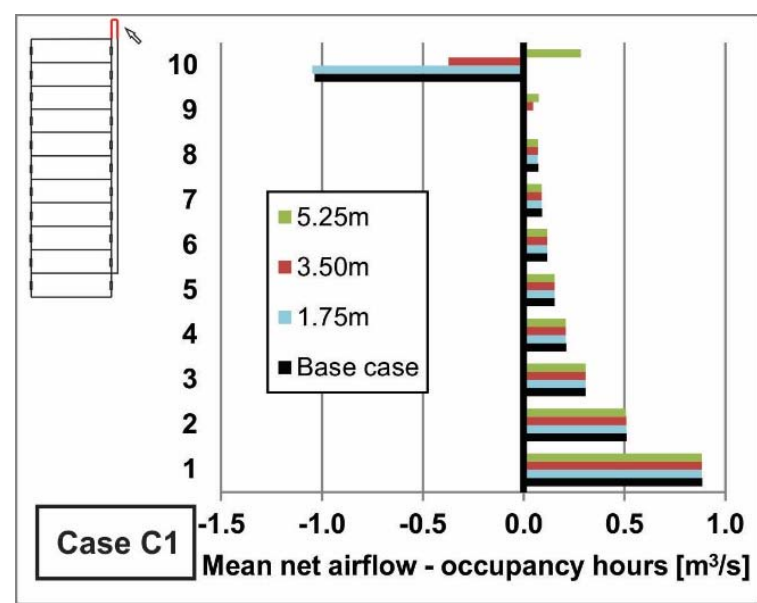

Figure 16 - Annual mean of the net airflow for each floor for parameter 'cavity extension above roof'

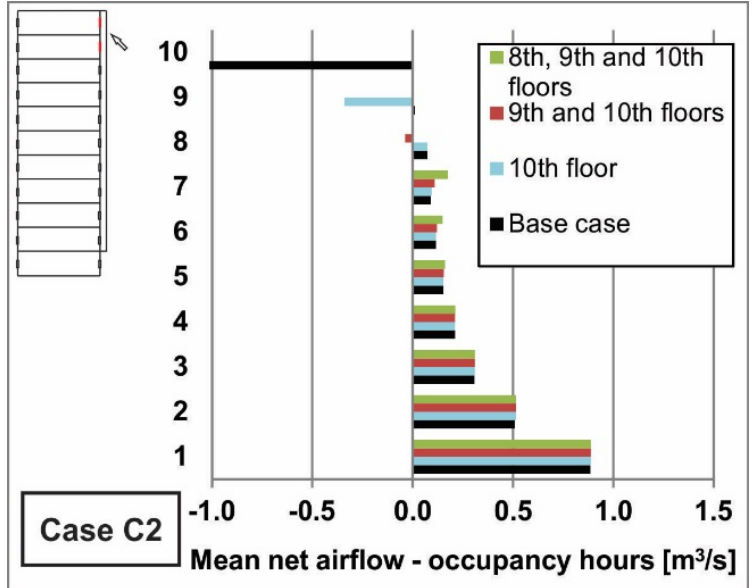

Figure 17 - Annual mean of the net airflow for each floor for parameter 'upper windows closed'

\subsection{Group D: tapered cavity and windows sizes}

Cases in this group aimed to achieve even flow through each floor by modifying the cavity width (cases D1) or adjusting the size, hence their resistances (case scenario D2.2) of the window openings. As shown in Figure 18 and Figure 19, net airflows of both alternatives were similar from the 1 st to 9 th floors. This strategy appeared effective in evening out airflows and consequently similar acceptable annual comfort levels of approximately $65 \%$ were achieved over all the floors, except for the top floor where only $45 \%$ of thermal acceptance was accomplished. 


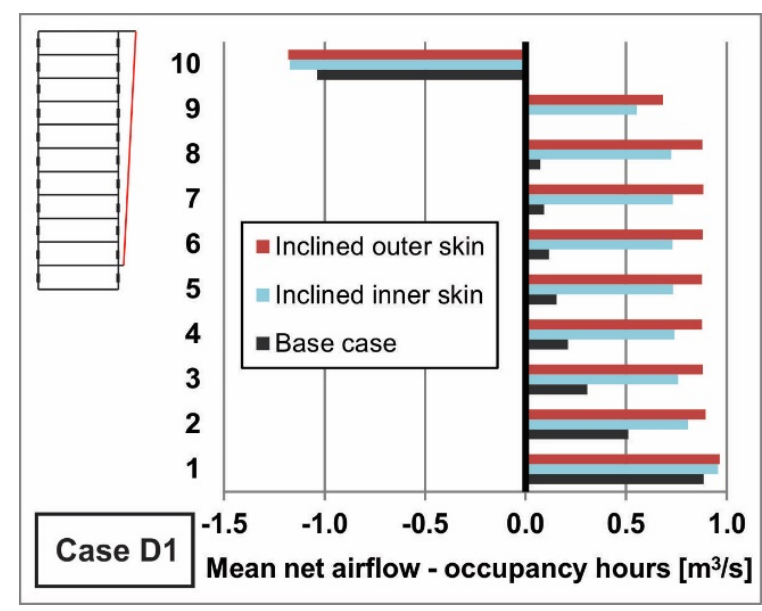

Figure 18 - Annual mean of the net airflow for each floor for parameter 'inclined skin'

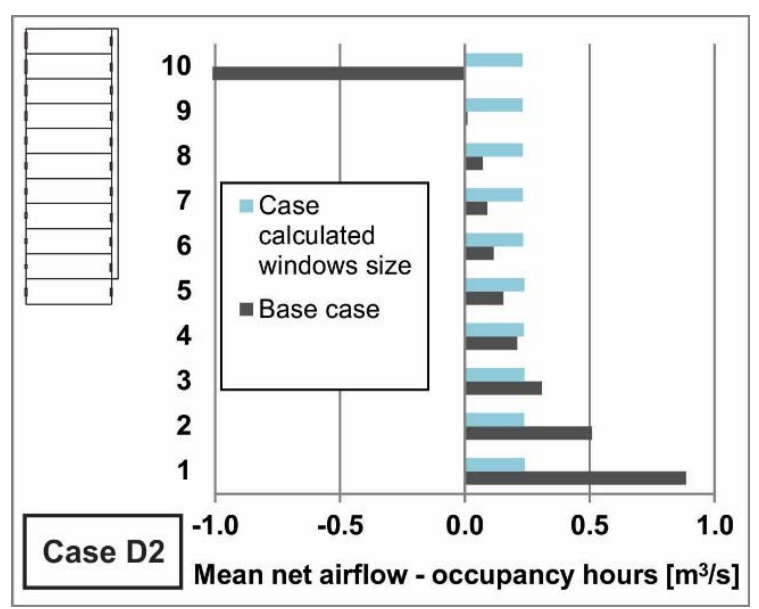

Figure 19 - Annual mean of the net airflow for each floor for parameter 'windows size'

Case scenario D2.2 demonstrated similar flow rates among all building levels could be achieved as illustrated in Figure 19. In this case, windows sizes were calculated such that the neutral pressure level occurs at a point above the highest window and the flows from each floor are balanced. Acceptable thermal comfort levels of around $64 \%$ were achieved.

\subsection{Acceptable thermal comfort comparison}

Table 4 presents the acceptable percentage of thermal comfort resulted on each floor for the cases simulated. It compares the thermal comfort acceptability of the alternate options applied in the models and highlights their relative effectiveness in improving the thermal comfort. Some alternatives improved the thermal comfort of the whole building, such as increasing the cavity width and applying shading devices, which enhanced the annual thermal comfort by up to $9 \%$ in comparison with the base case. Impacts of other parameters such as the cases of 'bottom closed' and 'windows position' were more specific to the bottom floor, where improvements of approximately $4 \%$ in the thermal acceptability were observed. By extending the cavity above the roof of the building, the problem of reverse flow on the top floor was resolved, which resulted in $9 \%$ of thermal comfort improvement on that floor. The strategies of inclining the outer skin and adjusting the flow resistances through calculation of window sizes according to their positions relative to the building height enabled attainment of desirable similar airflows on each floor, providing approximately $65 \%$ of thermal acceptability from the $1^{\text {st }}$ to the $9^{\text {th }}$ floor. 
Table 4 - Effect of design parameters to annual thermal comfort

\begin{tabular}{|c|c|c|c|c|c|c|c|c|c|c|c|c|c|}
\hline \multirow{3}{*}{$\begin{array}{c}\text { Design } \\
\text { parameter }\end{array}$} & \multirow[b]{2}{*}{ Scenario } & \multirow[b]{2}{*}{ Variable } & \multicolumn{10}{|c|}{ Annual thermal comfort acceptance (\%) } & \multirow[b]{2}{*}{$\begin{array}{l}\text { Mean } \\
\text { Overall }\end{array}$} \\
\hline & & & $\begin{array}{c}1^{\text {st }} \\
\text { floo } \\
r\end{array}$ & $\begin{array}{c}2^{\text {nd }} \\
\text { floo } \\
r\end{array}$ & $\begin{array}{c}3^{\text {rd }} \\
\text { floo } \\
r\end{array}$ & $\begin{array}{c}4^{\text {th }} \\
\text { floo } \\
r\end{array}$ & $\begin{array}{c}5^{\text {th }} \\
\text { floo } \\
r\end{array}$ & $\begin{array}{c}6^{\text {th }} \\
\text { floo } \\
r\end{array}$ & $\begin{array}{l}7^{\text {th }} \\
\text { floo } \\
r\end{array}$ & $\begin{array}{c}8^{\text {th }} \\
\text { floo } \\
r\end{array}$ & $\begin{array}{c}9^{\text {th }} \\
\text { floo } \\
r\end{array}$ & $\begin{array}{c}10^{\text {th }} \\
\text { floo } \\
r\end{array}$ & \\
\hline & Base case & $\begin{array}{l}\text { Refer to } \\
\text { Table } 3\end{array}$ & 70.2 & 67.8 & 65.8 & 64.1 & 63.0 & 61.7 & 61.1 & 60.2 & 58.5 & 43.9 & 61.6 \\
\hline \multirow{2}{*}{$\begin{array}{l}\text { Cavity } \\
\text { width }\end{array}$} & A1.1 & $25 \mathrm{~cm}$ & 67.4 & 64.3 & 62.0 & 60.7 & 59.8 & 59.3 & 58.7 & 57.9 & 56.9 & 44.8 & 59.2 \\
\hline & A1.3 & $100 \mathrm{~cm}$ & 72.0 & 70.8 & 68.8 & 67.3 & 66.0 & 65.1 & 64.1 & 62.9 & 59.4 & 42.2 & 63.9 \\
\hline \multirow{2}{*}{$\begin{array}{l}\text { Bottom } \\
\text { closed } \\
\text { Windows } \\
\text { position }\end{array}$} & A2.2 & $\begin{array}{l}\text { Bottom } \\
\text { cavity } \\
\text { closed }\end{array}$ & 74.7 & 67.8 & 65.0 & 63.5 & 62.0 & 61.3 & 60.8 & 60.0 & 58.2 & 43.8 & 61.7 \\
\hline & A 3.2 & $\begin{array}{l}\text { Up north, } \\
\text { bottom } \\
\text { south }\end{array}$ & 70.7 & 66.7 & 63.8 & 62.0 & 60.7 & 60.2 & 59.2 & 58.0 & 55.3 & 43.0 & 60.0 \\
\hline \multirow{3}{*}{$\begin{array}{c}\text { Shading } \\
\text { device } \\
\text { Inner skin } \\
\text { material }\end{array}$} & B1.2 & Concrete & 73.6 & 72.5 & 70.7 & 68.8 & 67.4 & 66.4 & 65.6 & 64.7 & 62.9 & 47.0 & 65.9 \\
\hline & B1.3 & Aluminium & 74.1 & 74.0 & 73.2 & 72.4 & 71.9 & 71.4 & 70.9 & 70.4 & 69.4 & 58.6 & 70.6 \\
\hline & B2.2 & $\begin{array}{l}\text { Reflective } \\
\text { glazing }\end{array}$ & 69.1 & 65.9 & 64.3 & 61.9 & 61.0 & 59.9 & 59.2 & 58.0 & 55.5 & 40.5 & 59.5 \\
\hline \multirow{3}{*}{$\begin{array}{l}\text { Cavity } \\
\text { extension }\end{array}$} & C1.2 & $1.75 \mathrm{~m}$ & 69.9 & 67.3 & 65.3 & 63.8 & 62.3 & 61.3 & 60.6 & 59.8 & 58.1 & 43.8 & 61.2 \\
\hline & C1.3 & $3.50 \mathrm{~m}$ & 69.9 & 67.3 & 65.3 & 63.8 & 62.3 & 61.3 & 60.6 & 59.9 & 58.6 & 47.8 & 61.7 \\
\hline & C1.4 & $5.25 \mathrm{~m}$ & 69.9 & 67.3 & 65.3 & 63.8 & 62.3 & 61.3 & 60.6 & 60.0 & 59.3 & 52.8 & 62.2 \\
\hline $\begin{array}{l}\text { Windows } \\
\text { closed }\end{array}$ & $\mathrm{C} 2.3$ & $9^{\text {th }}$ and $10^{\text {th }}$ & 70.4 & 68.0 & 65.9 & 64.4 & 63.2 & 61.5 & 58.6 & 41.3 & - & - & 61.6 \\
\hline \multirow{3}{*}{$\begin{array}{c}\text { Tapered } \\
\text { cavity } \\
\text { Calculated } \\
\text { windows } \\
\text { size }\end{array}$} & D1.2 & $\begin{array}{c}\text { Inclined } \\
\text { inner skin }\end{array}$ & 67.8 & 66.7 & 66.1 & 65.7 & 65.6 & 65.5 & 65.5 & 65.1 & 63.0 & 44.8 & 63.6 \\
\hline & D1.3 & $\begin{array}{l}\text { Inclined } \\
\text { outer skin }\end{array}$ & 68.6 & 67.5 & 66.7 & 65.9 & 65.6 & 65.4 & 65.3 & 64.8 & 62.6 & 44.7 & 63.7 \\
\hline & $\mathrm{D} 2.2$ & $\begin{array}{l}\text { Calculated } \\
\text { WWR }\end{array}$ & 64.5 & 63.9 & 63.9 & 63.9 & 63.9 & 63.8 & 63.8 & 63.4 & 62.8 & 54.8 & 62.9 \\
\hline
\end{tabular}

\subsection{Optimized cases}

Following a multitude of tests based on the outcomes of the evaluation on individual parameters, two optimized models utilising a combination of parameters to maximize thermal comfort were developed. These models maximized the absolute flow rates while resolving the reverse flow through the upper floors and attaining even airflows at each floor level. The characteristics of these two models are:

Optimised model 1 - the DSF cavity bottom is closed and $3.5 \mathrm{~m}$ extended (equivalent to one floor) above the roof. Concrete shading device is placed inside the cavity with white masonry wall inner layer. The outer DSF glazing is inclined outward such that similar horizontal flow rates across all floor levels. The windows of WWR of $40 \%$ are positioned at the bottom and on the top of the south and north walls respectively.

Optimised model 2 - the straight DSF cavity of $1 \mathrm{~m}$ has its bottom closed and it is extended $3.5 \mathrm{~m}$ above the roof. Windows are sized to achieve similar flowrates across all floors levels [9]. Concrete shading device is applied in the cavity with white masonry wall inner layer. 


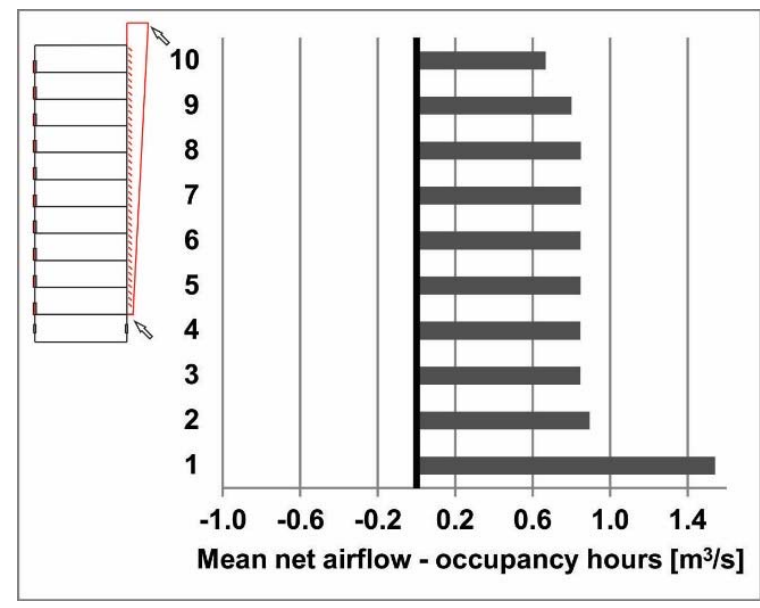

Figure 20 - Annual mean of the net airflow for each floor of 'Optimized model 1'

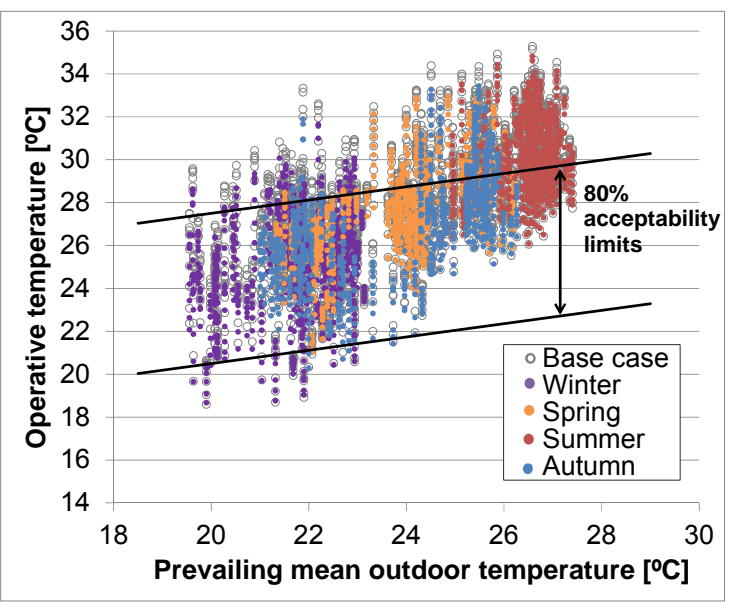

Figure 21 - Annual operative temperatures of 'Optimized model 1' ( $5^{\text {th }}$ floor) plotted on the ASHRAE [33] thermal comfort matrix

Results in Figure 20 to Figure 23 show that higher levels of thermal comfort acceptance were achieved by both models while similar airflows were generally maintained on all the floors. Net flow rates in optimized model 1 are marginally higher but the overall thermal comfort levels are similar at approximately $68 \%$ and $69 \%$ respectively. The top floor presented the lowest hours of thermal comfort acceptance of $58 \%$ in case 1 and $62 \%$ in case 2 due to the higher heat gain and minor reverse flow coming from the cavity. Hourly operative temperatures for the whole year are plotted in the adaptive comfort charts (Figure 21 and Figure 23) in colour to highlight the thermal acceptability according to the seasonal variations, which show that most of the uncomfortable hours occur when the prevailing mean outside temperature is above $24^{\circ} \mathrm{C}$.

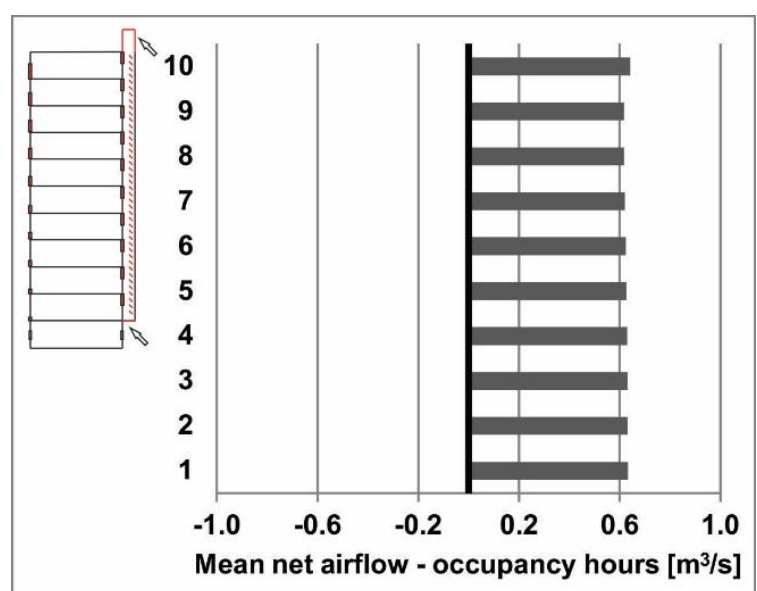

Figure 22 - Annual mean of the net airflow for each floor of 'Optimized model 2'

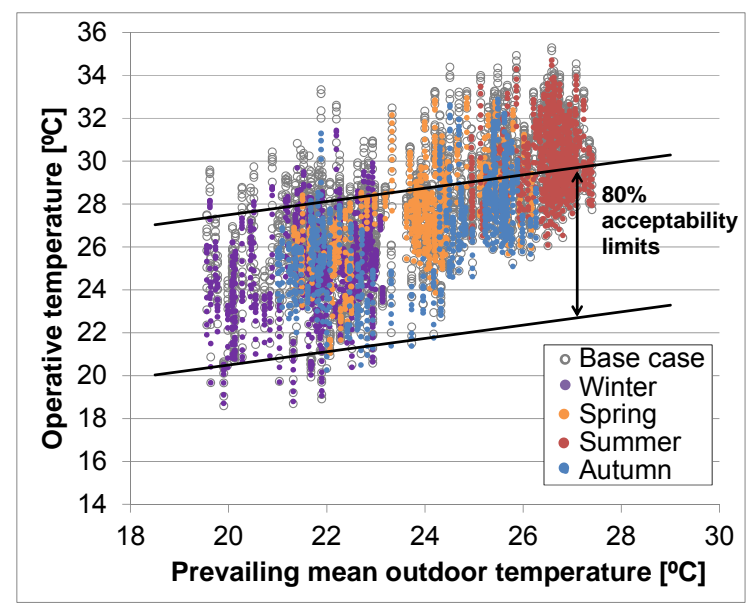

Figure 23 - Annual operative temperatures of 'Optimized model 2' (5 $5^{\text {th }}$ floor) plotted on the ASHRAE [33] thermal comfort matrix

\subsection{Conclusions}

This paper presents a fundamental study on the potential application of double skin façades (DSFs) in naturally ventilated office buildings under tropical climates. Using a reference model of an office building in Rio de Janeiro, the key DSF design parameters are individually evaluated and optimised design options that can 
maximize the annual acceptable comfort levels in the occupied space are established. Results show that the most influential parameters on the overall building thermal performance are the application of shading devices within the cavity, followed by the cavity width and tapered cavity with an inclined outer layer. Other alternatives such as the 'bottom closed' and 'window position' have improved comfort on specific floors while extending the cavity height by one and a half floor above the building roof proved to be effective in resolving the reverse flow resulting in thermal comfort improvement on the top floor.

Results of optimised models show that the incorporation of DSF is able to achieve approximately $70 \%$ of occupied hours within the acceptable comfort levels. Although the office buildings will still require other means of cooling during peak summer periods, the incorporation of DSF, potentially as a part of a mixed-mode ventilation strategy, will have significant impact to energy consumption.

\subsection{Acknowledgments}

This work was supported by the Brazilian Government Science without borders programme.

\subsection{References}

1. Mingotti, N., T. Chenvidyakarn, and A.W. Woods, The fluid mechanics of the natural ventilation of a narrow-cavity double-skin facade. Building and Environment, 2011. 46(4): p. 807823.http://dx.doi.org/10.1016/.j.buildenv.2010.09.015.

2. Choi, W., et al., Operation and control strategies for multi-storey double skin facades during the heating season. Energy and Buildings, 2012. 49(0): p. 454-465.http://dx.doi.org/10.1016/j.enbuild.2012.02.047.

3. Darkwa, J., Y. Li, and D.H.C. Chow, Heat transfer and air movement behaviour in a double-skin façade. Sustainable Cities and Society, 2014. 10(0): p. 130-139.http://dx.doi.org/10.1016/j.scs.2013.07.002.

4. Quesada, G., et al., A comprehensive review of solar facades. Transparent and translucent solar facades. Renewable and Sustainable Energy Reviews, 2012. 16(5): p. 26432651.http://dx.doi.org/10.1016/j.rser.2012.02.059.

5. Barbosa, S. and K. Ip, Perspectives of double skin façades for naturally ventilated buildings: A review. Renewable and Sustainable Energy Reviews, 2014. 40(0): p. 10191029.http://dx.doi.org/10.1016/i.rser.2014.07.192.

6. Ding, W., Y. Hasemi, and T. Yamada, Natural ventilation performance of a double-skin façade with a solar chimney. Energy and Buildings, $2005.237(4)$ p. $411-$ 418.http://dx.doi.org/10.1016/j.enbuild.2004.08.002.

7. Gratia, E. and A. De Herde, Is day natural ventilation still possible in office buildings with a double-skin façade? Building and Environment, $2004 . \quad 39(4): \quad$ p. $399-$ 409.http://dx.doi.org/10.1016/i.buildenv.2003.10.006.

8. Radhi, H., S. Sharples, and F. Fikiry, Will multi-facade systems reduce cooling energy in fully glazed buildings? A scoping study of UAE buildings. Energy and Buildings, 2013. 56(0): p. 179188.http://dx.doi.org/10.1016/j.enbuild.2012.08.030.

9. ASHRAE, Handbook-Fundamentals. 2005, American Society of Heating, Refrigerating and Air Conditioning Engineers: Atlanta, GA. 
10. CIBSE, Applications Manual AM10, in Natural ventilation in non-domestic buildings. 2005.

11. Lou, W., et al., Experimental and zonal modeling for wind pressures on double-skin facades of a tall building. Energy and Buildings, 2012. 54(0): p. 179-191.http://dx.doi.org/10.1016/i.enbuild.2012.06.025.

12. Torres, M., et al. Double skin facades - Cavity and exterior openings dimensions for saving energy on Mediterranean climate. in Building Simulation. 2007. Beijing, China.

13. Rahmani, B., M.Z. Kandar, and P. Rahmani, How Double Skin Façade's Air-Gap Sizes Effect on Lowering Solar Heat Gain in Tropical Climate? World Applied Sciences Journal 2012. 18: p. 774778.10.5829/idosi.wasj.2012.18.06.3184.

14. Ji, Y., et al. CFD modelling of double-skin facades with venetian blinds. in The 10th International Building Performance Simulation Association (IBPSA) Conference and Exhibition. 2007. Beijing, China.

15. Gratia, E. and A. De Herde, The most efficient position of shading devices in a double-skin facade. Energy and Buildings, 2007. 39(3): p. 364-373.http://dx.doi.org/10.1016/i.enbuild.2006.09.001.

16. Jiru, T.E., Y.-X. Tao, and F. Haghighat, Airflow and heat transfer in double skin facades. Energy and Buildings, 2011. 43(10): p. 2760-2766.http://dx.doi.org/10.1016/j.enbuild.2011.06.038.

17. Haase, M., F. Marques da Silva, and A. Amato, Simulation of ventilated facades in hot and humid climates. Energy and Buildings, 2009. 41(4): p. 361-373.http://dx.doi.org/10.1016/i.enbuild.2008.11.008.

18. Pérez-Grande, I., J. Meseguer, and G. Alonso, Influence of glass properties on the performance of double-glazed facades. Applied Thermal Engineering, 2005. 25(17-18): p. 31633175.http://dx.doi.org/10.1016/j.applthermaleng.2005.04.004.

19. Hong, T., et al., Assessment of Seasonal Energy Efficiency Strategies of a Double Skin Façade in a Monsoon Climate Region. Energies, 2013. 6(9): p. 4352-4376

20. Yılmaz, Z. and F. Çetintaş, Double skin façade's effects on heat losses of office buildings in Istanbul. Energy and Buildings, 2005. 37(7): p. 691-697.http://dx.doi.org/10.1016/j.enbuild.2004.07.010.

21. Chan, A.L.S., et al., Investigation on energy performance of double skin façade in Hong Kong. Energy and Buildings, 2009. 41(11): p. 1135-1142.http://dx.doi.org/10.1016/j.enbuild.2009.05.012.

22. Chou, S.K., K.J. Chua, and J.C. Ho, A study on the effects of double skin façades on the energy management in buildings. Energy Conversion and Management, 2009. 50(9): p. 22752281.http://dx.doi.org/10.1016/j.enconman.2009.05.003.

23. Pappas, A. and Z. Zhai, Numerical investigation on thermal performance and correlations of double skin façade with buoyancy-driven airflow. Energy and Buildings, 2008. 40(4): p. 466475.http://dx.doi.org/10.1016/j.enbuild.2007.04.002.

24. Carlo, J.C., Desenvolvimento de Metodologia de Avaliação da Eficiência Energética do Envoltório de Edificações Não-residenciais, in Civil Engineering. 2008, Federal University of Santa Catarina.

25. Voordt, T.J.M.V.d. and M. Maarleveld, Performance of office buildings from a user's perspective Ambiente Construído, 2006. 6: p. 7-20

26. ABNT, Desempenho térmico de edificações Parte 3: Zoneamento bioclimático brasileiro e diretrizes construtivas para habitações unifamiliares de interesse social. 2003, Associação Brasileira de Normas Técnicas. p. 23.

27. Morishita, C., et al., Catálogo de propriedades térmicas de paredes e coberturas. 2010, Federal University of Santa Catarina.

28. Oesterle, E., et al., Double Skin Facades - Integrated Planning, ed. P. Verlag. 2001, Munich: Prestel

29. IESVE, MacroFlo Calculation Methods. 2014. 
30. Hensen, J. and E. Djunaedy. Building simulation for making the invisible visible - air flow in particular. in International conference energy efficient technologies in indoor environment. 2005. Gliwice, Poland.

31. Alvares, C.A., et al., Koppen's climate classification map for Brazil. Meteorologische Zeitschrift, 2014. 22(6)

32. Schuch, M., et al., Analysis Bio. 2010, Laboratório de Eficiência Energética em Edificações.

33. ASHRAE, ASHRAE 55 - Thermal Environmental Conditions for Humam Occupancy. 2013, Ame: Atlanta. 